\title{
Another View of Little Old New York
}

Some interesting early American year books have come into the possession of the Library, one of them a gift of Professor A. H. Cole, a founder member. The first in point of time is The Picture of New York or The Traveller's Guide, dated 1807. This gives a full description of the situation and harbor, history, geography and geology, government, and the institutions and amusements of New York, and of the various pleasant excursions in that vicinity. Among the institutions, the volunteer fire company is described in detail. At every fire, the firemen of different ranks were there in full regalia, distinguished by white leather painted caps with gilded fronts, ornamented by the insignia of the engineers, fire wardens, or ordinary firemen. The mayor, recorder and aldermen were also supposed to be present, and could be known by their white wands with a gilded flame at the top. One of the accompanying cuts represents a fire company in action.

There is a gazetteer of New York State in 181 3, when New York City extended but two miles along the Hudson, and four miles along the East River. Even then, however, in population and trade it took the first rank in the Union, and although "the streets of the ancient or lower part, at the south end of the island, were irregular, many of them very narrow and crooked, with little adaptation to the ground, or to the convenience or elegance of the city, the northern part was laid out in much better taste. Many of these streets were very spacious, ran in right lines, and were intersected by others at right angles. And the quays and wharves were far extended into the original waters that almost surrounded the town."

Mr. Cole's gift, New York as it is, in 1837, and Citizen's Advertising Directory, takes up the New York of twenty odd years later, grown to $13 \frac{1}{2}$ miles in length, and containing about 270,100 inhabitants. The year book mentions, with the situation, harbor, and fortifications, a pre-electric telegraph established on the heights of Staten Island, communicating by semaphore signals with one in the city on Holt's Hotel. These telegraphs often relayed information for long distances, the first one being used between London and Portsmouth in the Napoleonic Wars.

The description continues with divisions of government, public buildings, gas-works, water-works, and the like. The New York 


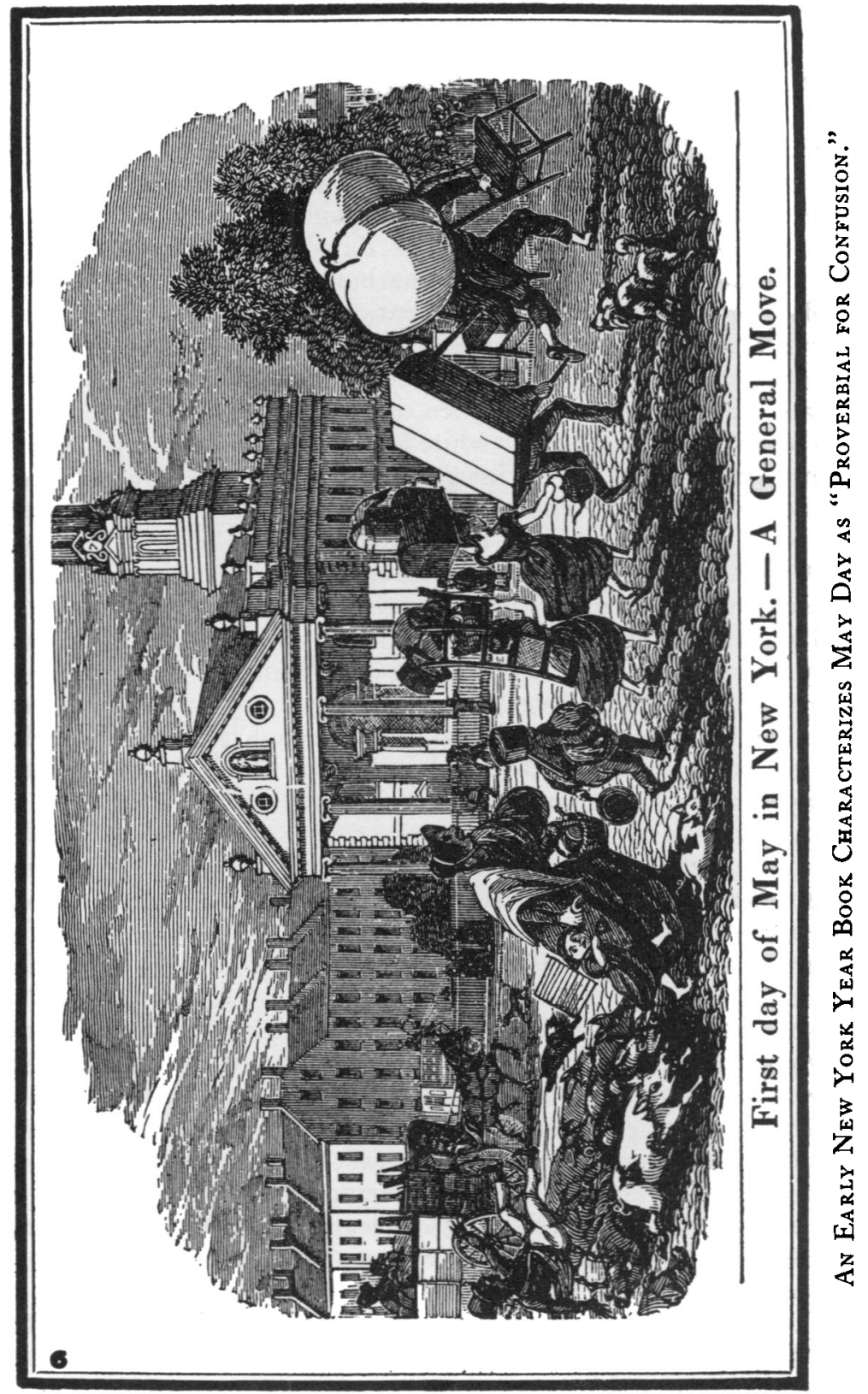


and Harlem Railroad Company expects an increase of passengers when the tunnel to Harlem is completed; and it is to be regretted that the city is destitute of a good wholesome supply of water. The Croton River has been suggested as a source of water for the city. The river is capable of furnishing $32,000,000$ gallons daily, while the present need is only 10,000,000. In our own day it is estimated that an average of a barrel a day per person is used in the United States. Dividing 10,000,000 by 270,000, the approximate population of New York City in I837, the result is about 37 gallons per person used every day at that time, seeming at first glance to show that the average of cleanliness has remained about stationary for a century. But in view of the law prohibiting bathtubs as injurious to health passed in 1840 , when the first one was introduced, it becomes a problem what the New Yorker of 1837 did with his daily barrel of water. The second cut reproduced with this article, taken from a comic almanac contemporary with the year book, is illustrative of the custom, which is still with us, of moving on the first of May, which had become a great evil, "May Day being proverbial for confusion, amounting to partial suspension of business."

The book goes on to cover New York in its various phases, from its cemeteries and monuments to the ships, brigs, schooners, and steamboats leaving daily, weekly, or monthly for Albany, New England, the South, the West Indies, and Liverpool. The manufactures in the City of New York comprised I4 iron works; rope walks and breweries, Io apiece; 9 distilleries; 6 saw mills; cotton factories and tanneries, 5 each; 4 glass factories; 2 grist mills; and a single paper mill; a trip hammer; and a woolen factory. The number of banks had risen since 1807 from five to twenty-three. In 1807 , there were many excellent seminaries in New York, and one free school. There were forty-nine public schools in 1837, of which eight were "African." The names of some of the societies and associations would have an unfamiliar sound to the modern New Yorker: the Anti-Slavery Society and the Colonization Society of New York, interested in the settlement of free negroes in Liberia; and the Ladies' Depository, an institution intended to give employment to "Ladies, who, by a reverse of fortune, are forced to depend on their own exertions." Perhaps our generation would appreciate a revival of the Society for the Encouragement of Faithful Domestic Servants. In the list of periodicals, there is a predominance of the religious element, and the Sun and James Gordon 
Bennett's Herald are listed as small dailies. Reading the list of city officials, one is struck by the character of the names, which run to Pearsalls, Allisons, Westcotts, and Schuylers, with an isolated Ahearn and Haggerty the exception rather than the rule. De Witt Clinton's name appears three times as mayor.

Toward the back of the book are regulations to be observed by the drivers of carriages and hackney coaches, for the fees of public porters and for the fees of chimney sweepers. Among other prohibitions, hackney coaches were not allowed to charge more than seventy-five cents for conveying a passenger to the New Alms House, and returning. Under amusements, there is a list of some five theatres, an increase of four over I807. It is to be hoped that these were equal to the original Playhouse in their interior finish and decoration, for there "the boxes were exceedingly well adapted to the display of beauty and fashion, as well as to the view of the scenic performances." There were two museums, and two principal baths for the accommodation of strangers and citizens, besides many others of lesser note. A favorite excursion was to Hoboken, a popular summer resort, and another to Coney Island, where there was a fine beach for bathing, with a public house, and other conveniences. The Battery appears as a beautiful promenade; its eleven acres laid out in grass-plots and gravel walks, and shaded with trees, with an expensive iron railing extending along the interior front, "justly commanding the admiration of every visiter." Perhaps the student of our past in its social and industrial phases can glean from the detailed and casual description in a small year book like this as vivid and intimate an impression of little old New York as from a more pretentious work.

\section{The Society Captures the Golden Fleece}

"The Golden Fleece; or the Trade, Interest, and Well Being of Great Britain," a recent acquisition of The Business Historical Society, is a rare pamphlet dated 1736 , which gives a contemporary summary of the wool situation in the seventeenth and early eighteenth centuries. From the time of Edward III, the petted woollen industry, for so long the pride of Britain, enjoyed the protection of the government. It was not until the seventeenth century, however, that the manufacture of woollen goods came to be-protected and fostered at all costs. Raw wool was not allowed to leave the 